\title{
GROUNDWATER QUALITY DYNAMICS IN THE TERRITORY OF FORMER PESTICIDE WAREHOUSE
}

\begin{abstract}
Laima ČESONIENÉ, Institute of Environment and Ecology, Faculty of Forest Science and Ecology, Aleksandras Stulginskis University, Studentų g. 11, LT-53361 Akademija, Kauno raj., Lithuania, laima.cesoniene@asu.lt (corresponding author)

Kristina LINGYTÉ, Institute of Environment and Ecology, Faculty of Forest Science and Ecology, Aleksandras Stulginskis University, Studentų g. 11, LT-53361 Akademija, Kauno raj., Lithuania,kristina.lingyte@asu.lt

Daiva ŠILEIKIENÉ, Institute of Environment and Ecology, Faculty of Forest Science and Ecology, Aleksandras Stulginskis University, Studentų g. 11, LT-53361 Akademija, Kauno raj., Lithuania,daiva.sileikiene@ asu.lt

Midona DAPKIENÉ, Institute of of Hydraulic Engineering, Faculty of Water and Land Management, Aleksandras Stulginskis University, Studentu g. 11, LT-53361 Akademija, Kauno raj., Lithuania, midona.dapkiene@asu.lt

Pesticides are used in intensive farming to help fight plant pests and diseases (insecticides, fungicides), kill weeds (herbicides), as well as accelerate the growth of seeds (defoliants), but until 1992 pesticides were kept in improperly equipped warehouses, there was no maintenance or accounting of the pesticides. Consequently, the environment of the warehouse was often polluted. Such sources of pollution are hazardous to the environment. Economic activities in the area have been carried out from 1980 to 1994 . Various agricultural chemicals have been stored and used there. Later, in 1997, chemicals (fertilizers and plant protection chemicals) stored in the territory of the warehouse have been collected and removed from the territory. During the inventory of 2009 , no chemical substances were found in the territory. In 2010, an investigation carried out in the territory of the pesticide warehouse revealed unacceptable levels of pollution in the soil and the groundwater by pesticides and other toxic and neutral chemicals. In 2012, the polluted territory was cleaned eliminating the remains of buildings, and removing the soil polluted by the pesticides. The aim of the study was to evaluate the impact of the territory of the former pesticide warehouse in Kaunas District Municipality, Bubiu Village on the groundwater during the period from 2012 to 2016 . The results have shown that the groundwater is mostly polluted with nitrogen compounds, as well as the tendency in increase of chlorides, sodium, and calcium. Minimum and unchanging concentrations of the pesticides (DDD, DDE, DDT) were determined throughout the investigation.
\end{abstract}

Keywords: concentrations, groundwater, pesticides.

\section{INTRODUCTION}

In agriculture pesticides are used in order to ensure sufficient yield and quality, however at the same time pesticides pose risk to the quality of soil, water and air. And even then pesticides are used for their intended purpose, only a small amount of them reaches the target, and the remaining pesticides become short-term or long-term sources of pollution (Hvězdová M. et. al 2017). Groundwater is one of the most important and the largest sources of fresh water in the European Union. However, excessive and inappropriate quantities of pesticides used in agriculture pose significant risk to the environment (McManus et al 2017, Köck-Schulmeyer et al. 2014), high vulnerability of groundwater poses risk to the natural and anthropogenic activities (Zhao Y.Y., Pei Y.S. 2012).

Stockholm Convention on Persistent Organic Pollutants states that currently only environmentally friendly pesticides are used and the use of chlorinated organic pesticides is prohibited (UNEP, 2016). Their higher efficiency in pest control (allowing reduction of doses) results in less durability and non-target toxicity. Nevertheless, the majority of the pesticides currently used in the world are sufficiently persistent and toxic (Chambers et al 2014; Hayes, 2009; Hester et al, 2012; Hrouzková and Matisová, 2012).

Pesticides are integrated complex compounds. According to stability pesticides are classified into easily biodegradable and persistent compounds, which remain in the ecosystem in their original or modified form for quite a long time. Introduced into the soil pesticides or their compounds are absorbed, washed out or evaporated.

Synthesized pesticides are hardly soluble in water, their release from the soil is slow and even though not used for years they may still be found in water (Barchanska et al., 2017; Mortl et al., 2010; Vonberg et al., 2014a; Vonberg et al., 2014b). Until 1992, pesticides in Lithuania were kept in improperly equipped warehouses, there was no maintenance or accounting thereof. Consequently, the environment of the warehouse was often polluted. Such sources of pollution are hazardous to the

Copyright (C) 2017 The Authors. Published by Aleksandras Stulginskis University. This is an open-access article distributed under the terms of the Creative Commons Attribution License (CC-BY 4.0), which permits unrestricted use, distribution, and reproduction in any medium, provided the original author and source are credited. 
environment. Approximately fifteen hundred of pesticide storage places were inventoried in Lithuania and few of them only were tested. (Mikilevičius M. 2010). The highest levels of pesticide pollution are observed in groundwater and soil, while the main and mostly monitored pools of the pesticides are pesticide repositories and warehouse fires. The effects of these substances on the environment are irreversible, manifested in a variety of divergences and diseases of people, animals and plants (Taurozaite K. 2010). Economic activities in the area under investigation have been carried out from 1980 to 1994. Various agricultural chemicals have been stored and used there. Later, in 1997, the chemicals (fertilizers and plant protection chemicals) stored in the territory of the warehouse have been collected and removed from the territory. During the inventory carried out in 2009 , no chemical substances were found in the territory. In 2010, an investigation carried out in the territory of the pesticide warehouse revealed unacceptable levels of pollution in the soil and the groundwater by pesticides and other toxic and neutral chemicals. In 2012, the polluted territory was cleaned eliminating the remains of buildings, and removing the soil polluted by the pesticides. The aim of the study was to evaluate the impact of the territory of the former pesticide warehouse in Kaunas District Municipality, Bubiu Village, on the groundwater during the period from 2012 to 2016.

\section{RESEARCH OBJECT AND METHODS}

The object of the study is the groundwater in the territory of the former cleaned pesticide warehouse in Kaunas District Municipality, Bubių Village.

The territory is located in the western part of Bubiu village, 400 meters away from the centre of the village. The land plot covers an area of 0.67 hectares. The coordinates of its centre of reference in LKS-94 coordinate system are as follows: $\mathrm{x}=6095214$, $\mathrm{y}=476241$.

The land plot covers an area of 0.67 hectares and is currently owned by the state. No immovable property (buildings or facilities) remained in the territory after the arrangement of the polluted area.

Characteristics of the Economic Activities. In the Soviet period the warehouse and the surrounding territories were owned by the Batniava horticulture farm. There were three buildings on the Soviet farm: seed treatment station, fertilizer and pesticide warehouses. The economic activities in the territory have been carried out during the period from 1980 to 1994. Various chemicals used in agriculture have been stored in the area. After the collapse of the Soviet farms, in 1997 the fertilizers and plant protection products stored in the area have been collected and removed from the territory. During the inventory carried out in 2009 , no chemical substances were found in the territory.

In 2012, the polluted territory was cleaned eliminating the remains of buildings, and removing the soil polluted by the pesticides. No economic activities are currently carried out in the territory.

Substances with potential effects on groundwater. With respect to the economic activities carried out in the area the substances which have been used the most and may have been absorbed into the groundwater were various pesticides (including DDT, aldrin, lindane, hexachlorobenzene, fosulin, nitrofen, etc.), mineral fertilizers (including nitrogen, phosphorus, potassium, etc.) and chemical substances (including copper sulfate). Preliminary and detailed ecogeological research has revealed impermissible levels of soil contamination with chlorinated organic pesticides $(\mathrm{HCB}, \mathrm{HCH}$, dieldrin and 4.4 DDT) as well as impermissible levels of groundwater contamination with chlorinated organic pesticides (dominated by $\mathrm{HCH}$ and heptachlor) and pollution with nitrogen, phosphorus compounds and sulfate. All of these substances can contaminate groundwater. With respect to the nature of the pollution, this would be combined pollution of toxic (e.g. pesticides, nitrates) and neutral (e.g. sulfate) substances. In all years of research water samples are taken six times a year - three times in spring and three times in autumn (monthly).

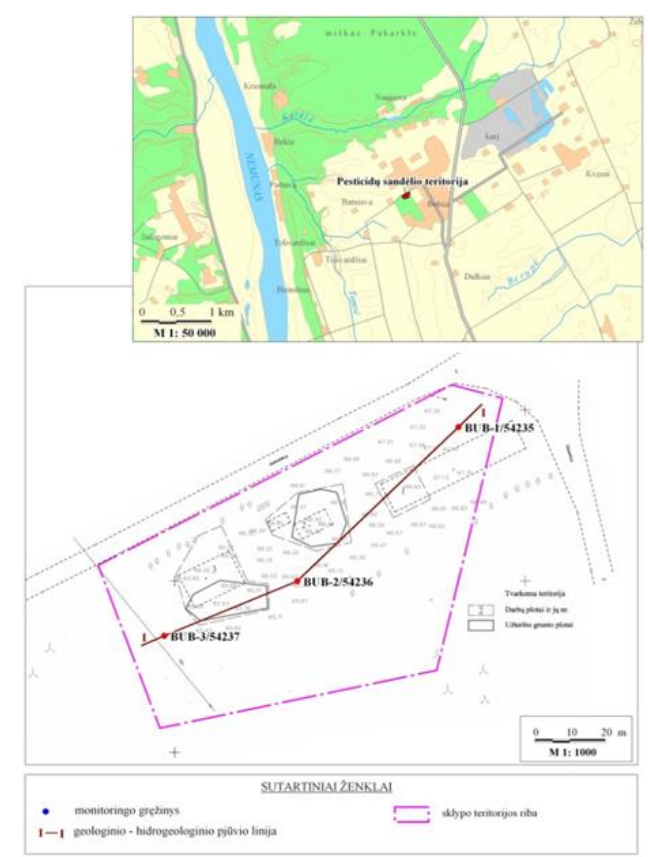

Figure 1. Diagram of the Location of the Former Pesticide Warehouse and the Actual Study Material 
The monitoring network for the entity's impact on the groundwater (Fig. 1) consisted of three monitoring wells No. 54235, No. 54236 and No. 54237 installed in the groundwater layer.

Indicators of the problematic chlorinated organic pesticide concentration and general parameters of drinking water quality were analyzed. Chlorinated organic pesticides DDE, DDD, DDT, Aldrin, Dieldrin, Endrin, and Heptachlor were analyzed.

Toxic (chemical) water quality indicators, including $\mathrm{pH}$, specific electrical conductivity, potassium permanganate index, nitrates, nitrites, ammonium, chlorides, sulfates, hydrocarbonate, sodium, potassium, calcium, were tested.

The dynamics of water quality parameters was evaluated using the linear regression equations and calculating the determination coefficient. Determination coefficient is the most important characteristic of model's applicability to data, which is mandatory in all regression model descriptions. The determination coefficient compares the differences between the $\mathrm{Y}$ values (concentrations), with the differences between the $\mathrm{X}$ values (year of the study) when the model is not taken into account. A very approximate interpretation of $\mathrm{R}^{2}$, contributing to a better understanding of its meaning, is as follows: how many percent of $\mathrm{Y}$ behaviour is explained by the behaviour of variables $\mathrm{X}$. The determination coefficient attains values from the interval $[0,1]$. The higher the value of the coefficient, the more applicable is the model to the data.

\section{RESULTS}

\section{Groundwater Quality Dynamics during the Period of 2012-2016}

In order to determine the Dynamics of groundwater quality, the average values of water quality indicators in the wells BUB-1; BUB-2 and BUB-3 were obtained.

Table 1. Average Values of the General Drinking Water Quality Indicators in 2012-2016

\begin{tabular}{|c|c|c|c|c|c|c|}
\hline & 2012 & 2013 & 2014 & 2015 & 2016 & $\begin{array}{c}\text { Linear trend equation } \\
\text { Determination factor }\end{array}$ \\
\hline $\mathrm{PI} \mathrm{mgO}_{2} \mathrm{l}^{-1}$ & 11,83 & 18,46 & 42,08 & 11,65 & 41,69 & $\begin{array}{c}\mathrm{y}=5,2897 \mathrm{x}+9,2719 \\
\mathrm{R}^{2}=0,2901\end{array}$ \\
\hline $\mathrm{NO}_{3}, \mathrm{mg} \mathrm{l}^{-1}$ & 544 & 861 & 1583 & 738 & 573 & $\begin{array}{c}\mathrm{y}=-6,5389 \mathrm{x}+879,29 \\
\mathrm{R}^{2}=0,0006\end{array}$ \\
\hline $\mathrm{NO}_{2}, \mathrm{mg} \mathrm{l}^{-1}$ & 1,44 & 3,23 & 15,24 & 3,78 & 31,96 & $\begin{array}{c}\mathrm{y}=6,1589 \mathrm{x}-7,3447 \\
\mathrm{R}^{2}=0,5738\end{array}$ \\
\hline $\mathrm{NH}_{4}, \mathrm{mg} \mathrm{l}^{-1}$ & 60,30 & 200,95 & 153,28 & 218,82 & 2,69 & $\begin{array}{c}\mathrm{y}=-9,7346 \mathrm{x}+156,41 \\
\mathrm{R}^{2}=0,0275\end{array}$ \\
\hline $\mathrm{SO}_{4}, \mathrm{mg} \mathrm{l}^{-1}$ & 127,93 & 112,31 & 208,20 & 90,50 & 137,06 & $\begin{array}{c}\mathrm{y}=-0,3567 \mathrm{x}+136,27 \\
\mathrm{R}^{2}=0,0002\end{array}$ \\
\hline $\mathrm{Cl}_{1} \mathrm{mg} \mathrm{l}^{-1}$ & 36,57 & 63,58 & 170,75 & 56,78 & 96,32 & $\begin{array}{c}\mathrm{y}=11,271 \mathrm{x}+50,986 \\
\mathrm{R}^{2}=0,1146\end{array}$ \\
\hline $\mathrm{HCO}_{3}, \mathrm{mg} \mathrm{l}^{-1}$ & 193,00 & 342,34 & 634,61 & 321,44 & 273,22 & $\begin{array}{c}\mathrm{y}=13,954 \mathrm{x}+311,06 \\
\mathrm{R}^{2}=0,0173\end{array}$ \\
\hline $\mathrm{Na}, \mathrm{mg} \mathrm{l}^{-1}$ & 19,03 & 16,77 & 24,14 & 15,77 & 53,83 & $\begin{array}{c}\mathrm{y}=6,8601 \mathrm{x}+5,3291 \\
\mathrm{R}^{2}=0,463\end{array}$ \\
\hline $\mathrm{K}, \mathrm{mg} \mathrm{l}^{-1}$ & 20,23 & 71,44 & 155,59 & 49,94 & 98,12 & $\begin{array}{c}\mathrm{y}=13,426 \mathrm{x}+38,786 \\
\mathrm{R}^{2}=0,1703\end{array}$ \\
\hline $\mathrm{Ca}, \mathrm{mg} \mathrm{l}^{-1}$ & 219,33 & 190,06 & 237,23 & 140,80 & 269,17 & $\begin{array}{c}\mathrm{y}=5,0411 \mathrm{x}+196,19 \\
\mathrm{R}^{2}=0,0267\end{array}$ \\
\hline
\end{tabular}

The maximum permanganate index concentrations were in 2014 and 2016, when they amounted to $42.08 \mathrm{mg} / \mathrm{l}$ $\mathrm{O}_{2}$ and $41.7 \mathrm{mg} / 1 \mathrm{O}_{2}$, and the lowest concentration was in $2015-11.6 \mathrm{mg} / 1 \mathrm{O}_{2}$. In 2012, it was $11.8 \mathrm{mg} / 1 \mathrm{O}_{2}$, and in 2013 an increase of $18.46 \mathrm{mg} / 1 \mathrm{O}_{2}$ was observed. Application of the linear trend has revealed the increasing tendency of the average value of permanganate index. The value of the determination coefficient shows that there is a 29 per cent probability that the permanganate index value will increase.

The lowest nitrate concentration determined in 2012, it was $544 \mathrm{mg} / \mathrm{l}$, however, from 2013 the nitrate concentration started to increase $(861 \mathrm{mg} / \mathrm{l})$ and in 2014 it has reached its peak concentration for the total period of the study $(1583 \mathrm{mg} / \mathrm{l})$, followed by a decrease in nitrate concentration the next year $(738 \mathrm{mg} / \mathrm{l})$ and in 2016 nitrate ion concentrations determined were similar $(573 \mathrm{mg} / \mathrm{l})$ to the nitrate ion concentrations of 2012 . Very low determination coefficient value shows high dispersion of the data, therefore it is impossible to predict the concentration of nitrates according to the linear model.

The lowest nitrite concentration was observed at the beginning of the study $(1.44 \mathrm{mg} / \mathrm{l})$, however each year the concentration of nitrites in the water of the wells increased and in 2016 it has reached its peak concentration of $32.1 \mathrm{mg} / \mathrm{l}$. High value of determination coefficient shows a $57 \%$ probability that the nitrite concentration will increase. The nitrite concentration can be predicted based on the regression equation obtained.

Ammonium ion concentration was one of the lowest at the beginning of the study $(60.30 \mathrm{mg} / \mathrm{lin} 2012)$, and in the following years an increase of the concentration was observed in the water of the wells. The peak concentration was determined in 2015 (218.8 mg/l), but in 2016 steep drop in ammonium ions to $2.69 \mathrm{mg} / \mathrm{l}$ was determined. Application of the linear trend revealed poor trend of decrease in ammonium ion concentration. Very low determination coefficient value 
shows high dispersion of the data, therefore it is impossible to predict the concentration of ammonium ion concentration according to the linear trend.

The maximum chloride concentration was determined in 2014, when it amounted to $170.75 \mathrm{mg} / \mathrm{l}$. The minimum average chloride concentration of $36.6 \mathrm{mg} / \mathrm{l}$ was observed in 2012 and 2013 . In 2015 and 2016, the average vales of chloride concentration were similar, but application of the linear trend revealed the trend of increase in chloride concentration. The value of the determination coefficient shows $11 \%$ probability of the increase in chloride concentration.

The maximum concentration of sulfates $(208.20 \mathrm{mg} / \mathrm{l})$ was determined in 2014 , and the minimum concentration of sulfates was observed in 2015, when it was $90.5 \mathrm{mg} / \mathrm{l}$. The results of 2012, 2013 and 2016 were similar - $127.9 \mathrm{mg} / \mathrm{l}$, $112.31 \mathrm{mg} / \mathrm{l}$ and $137.4 \mathrm{mg} / \mathrm{l}$. Application of the linear trend revealed constant concentration of sulfates in the water of the wells over the period of five years.

The maximum concentration of hydrcarbonates $(634.6 \mathrm{mg} / \mathrm{l})$ was determined in 2014 , and the minimum concentration of the hydrcarbonates was in 2012, when it was $193 \mathrm{mg} / \mathrm{l}$. Similar concentrations of the hydrocarbonates were observed in 2013, 2015 and 2016. Application of the linear trend revealed constant concentration of hydrcarbonates in the water of the wells over the period of five years.

The maximum concentration of sodium $(53.8 \mathrm{mg} / \mathrm{l})$ was determined in 2016. Over the other years the concentrations of sodium in the water of the wells were similar. Application of the linear trend revealed a tendency of increase in the concentration of sodium. The value of the determination coefficient shows $46 \%$ probability of increase in sodium concentration.

The maximum concentration of potassium $(155.59 \mathrm{mg} / \mathrm{l})$ was determined in 2014 . The minimum average concentration of potassium ( $20.23 \mathrm{mg} / \mathrm{l})$ was in 2012. Application of the linear trend revealed a tendency of increase in the concentration of potassium. The value of the determination coefficient shows $17 \%$ probability of increase in potassium concentration.

The maximum concentration of calcium $(269.17 \mathrm{mg} / \mathrm{l})$ was determined in $2016 \mathrm{~m}$. there was no significant differences in the concentration in 2014 (237.23 mg/l). The lowest concentration of calcium - $140.80 \mathrm{mg} / \mathrm{l}-\mathrm{was}$ determined in 2015 and 2013 when it amounted to $190 \mathrm{mg} / \mathrm{l}$. Application of the linear trend revealed a tendency of increase in the concentration of calcium. The value of the determination coefficient shows $3 \%$ probability of increase in calcium concentration.

Fig. 2 shows the Dynamics in the results of pesticide (DDE (dichlorodiphenyldichloroethylene), DDD (dichlorodiphenyldichloroethane), DDT (dichlorodiphenyltrichloroethane), aldrin, dieldrin, endrin, heptachlor) tests in 2012-2016 in the groundwater of the cleaned territory of the former pesticide warehouse.The limit values for chlorinated organic pesticides in soil, ground and groundwater were assessed in accordance with the requirements set out in the Order of the Minister of Environment of the Republic of Lithuania on the management of the territories contaminated with chemical substances, specifying that the maximum permissible concentration of DDE in the groundwater shall not exceed $20 \mu \mathrm{g} / 1$. The data in the Figure show that the maximum permissible concentration (MPC) was exceeded in any year, but in 2013 an increase of $0.03 \mu \mathrm{g} / 1$ in DDE concentration is observed. The lowest value of $0.006 \mu \mathrm{g} / 1 \mathrm{was}$ in 2012 . Determination coefficient shows a $2 \%$ probability that the concentration of DDE will further increase.

The maximum permissible concentration of DDD in groundwater is $6 \mu \mathrm{g} / \mathrm{l}$. The data provided show that the limit value was not exceeded in any year. The maximum concentration of the DDD $(0.04 \mu \mathrm{g} / \mathrm{l})$ was determined in 2015. The minimum value of the pesticide was determined in 2012, when it was $0.005 \mu \mathrm{g} / \mathrm{l}$. In 2014 and 2013 the average values of the pesticide were $0.02 \mu \mathrm{g} / 1$, and in $2016-0.01 \mu \mathrm{g} / \mathrm{l}$. According to the data provided, it is evident that the concentration of DDD pesticides has a tendency to increase and there is a $12 \%$ probability that in the following years its concentration will increase.

The maximum permissible concentration of DDT in groundwater is $6 \mu \mathrm{g} / \mathrm{l}$. The data provided show that the MPC of the pesticide was not exceeded in any year. The maximum concentration is observed in 2014 and $2016-0.09 \mu \mathrm{g} / \mathrm{l}$. In 2012, the lowest average value of $0.007 \mu \mathrm{g} / 1$ was determined. In 2015, the concentration of DDT pesticides amounted to $0.04 \mu \mathrm{g} / \mathrm{l}$. And in 2013 it was already $0.056 \mu \mathrm{g} / 1$. According to the value of the determination coefficient there is a $45 \%$ probability that the average value of the DDT will increase.

The maximum permissible concentration of aldrin in groundwater is $1 \mu \mathrm{g} / \mathrm{l}$. The data provided show that the MPC of the pesticide was not exceeded in any year. The lowest concentration $(0,004 \mu / 1)$ of aldrin pesticides was determined in 2012. During the period of 2013-2016, the concentration of aldrin was constant amounting to $0.01 \mu \mathrm{g} / \mathrm{l}$. According to the value of the determination coefficient there is a $50 \%$ probability that the concentration of aldrin will increase.

The maximum permissible concentration of dieldrin in groundwater is $0.1 \mu \mathrm{g} / \mathrm{l}$. The figure provided shows that the MPC of the pesticide was not exceeded in any year. The groundwater tests carried out show that there were no changes in the dieldrin concentration from 2012.

The maximum permissible concentration of endrin in groundwater is $0.1 \mu \mathrm{g} / \mathrm{l}$. The MPC in the samples tested was not exceeded. The data provided show that the concentration of endrin (same as aldrin) did not change from 2013 , and the lowest concentration of endrin was in $2012-0.004 \mu \mathrm{g} / \mathrm{l}$. The results obtained revealed that pesticide endrin has a tendency of increase and the determination coefficient shows that the average values of endrin will increase (probability of $50 \%$ ). 

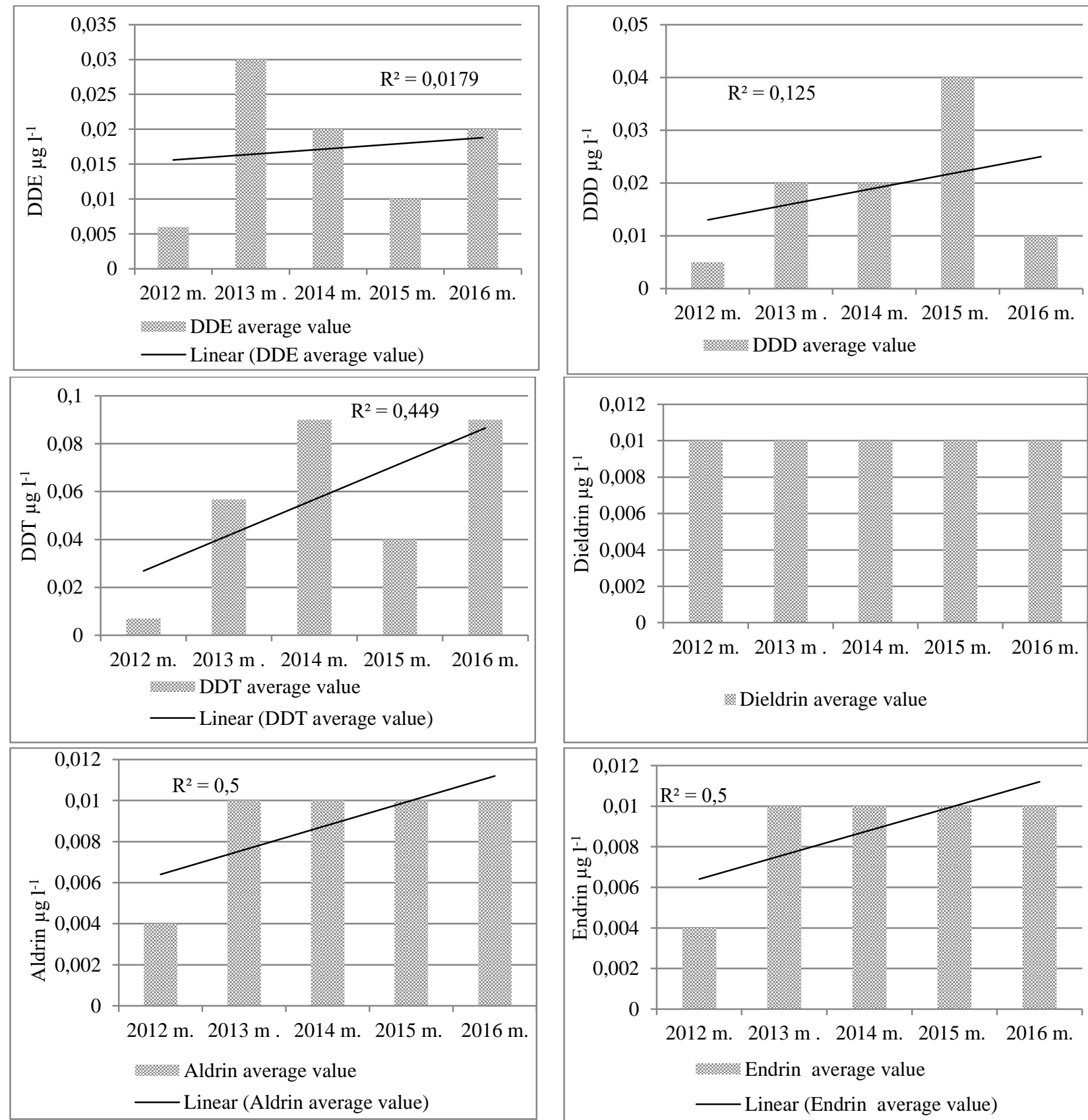

: Dieldrin average value
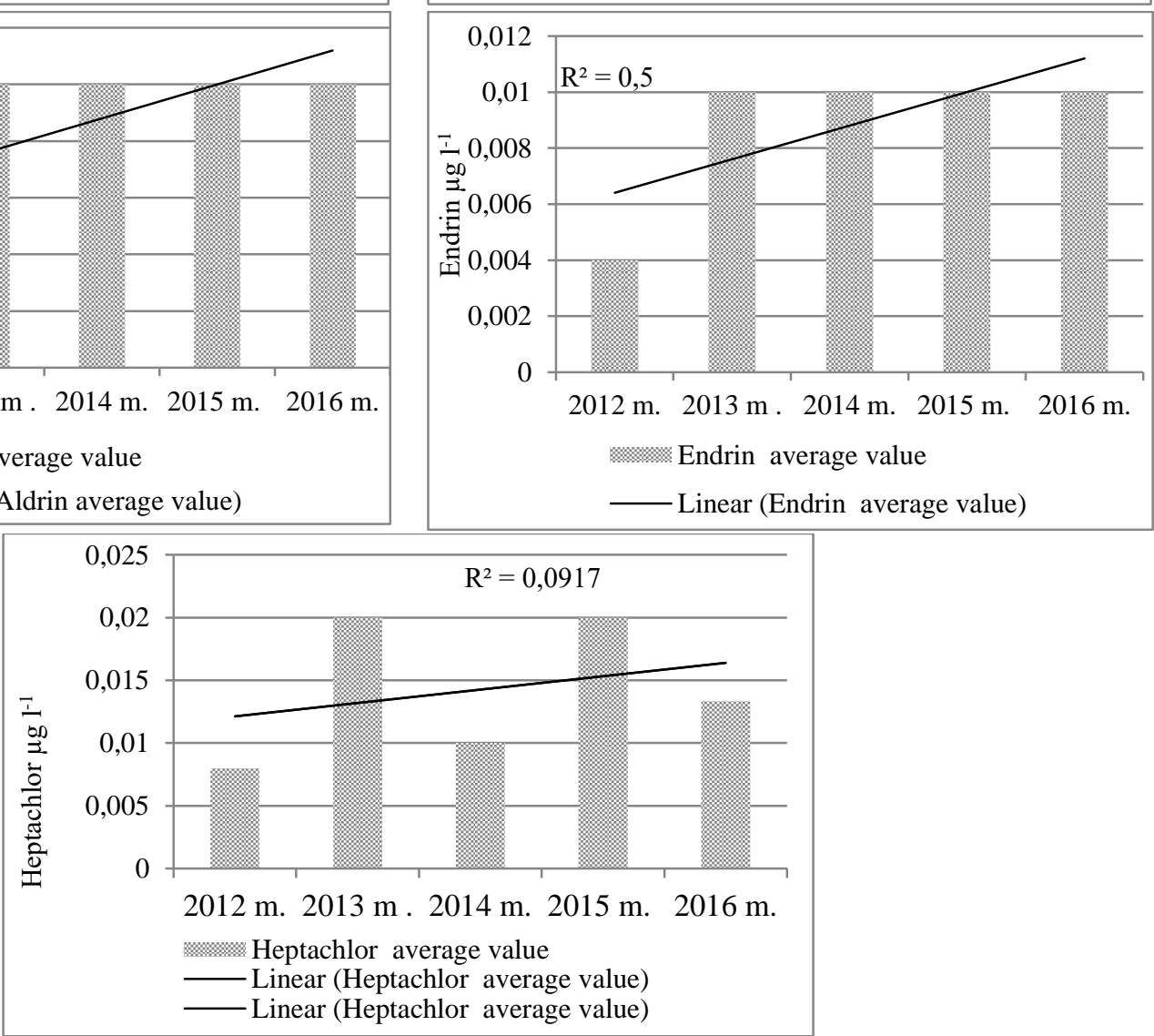

Figure 2. Dynamics in the results of pesticide (DDE (dichlorodiphenyldichloroethylene), DDD (dichlorodiphenyldichloroethane), DDT (dichlorodiphenyltrichloroethane), aldrin, dieldrin, endrin, and heptachlor) tests in 2012-2016 in the groundwater of the cleaned territory of the former pesticide warehouse.

The maximum permissible concentration of heptachlor in groundwater is $0.3 \mu \mathrm{g} / \mathrm{l}$. The data in the figure show that the MPC of the pesticide was not exceeded in any year. However, the data provided show that heptachlor pesticide has a tendency to increase and the determination coefficient shows $10 \%$ probability that the average value will increase. The 
highest concentration of heptachlor $(0.02 \mu \mathrm{g} / \mathrm{l})$ was determined in 2015 and 2013 , the lowest average value of $0.008 \mu \mathrm{g} / 1$ was determined in 2012 .

\section{CONCLUSIONS}

It is difficult to distinguish the cleanest and the most polluted well according to the intensity of pollution. Furthermore, the nature of the pollution in all three wells is different. The highest concentration of pesticides was recorded in the water of the well BUB-2/54236, the most intense pollution by nitrogen compounds was found in the water of the well BUB-3/54237. The intense pollution by mineral nitrogen compounds is a clear consequence of the activities of former chemical (pesticide) warehouse. The reason for the increase of the organic chemical in the water is most likely determined by the activity of microorganisms activated by high concentrations of biogenic elements (favourable nutritional conditions), not by direct contamination. Water in all three monitoring wells is heavily polluted. However, it can be noted that the most polluted groundwater was in 2014. The main factor shaping the chemical composition of the groundwater are the chemicals released into the ground during operation of the pesticide warehouse.

\section{REFERENCES}

1. Barchanska, H., Sajdak, M., Szczypka, K., Swientek, A., Tworek, M., Kurek, M., 2017. Atrazine, triketone herbicides, and their degradation products in sediment, soil and surface water samples in Poland. Environ. Environmental Science and Pollution Research, Vol. 24, pp. 644-658. https://doi.org/10.1007/s11356-016-7798-3

2. Chambers, J.E., Greim, H., Kendall, R.J., Segner, H., Sharpe, R.M., Van Der Kraak, G., 2014. Human and ecological risk assessment of a crop protection chemical: a case study with the azole fungicide epoxiconazole. Critical Reviews in Toxicology, Vol. 44, pp. 176-210. https://doi.org/10.3109/10408444.2013.855163

3. Hayes, T., 2009. More feedback on whether atrazine is a potent endocrine disruptor chemical. Environ. SciTechnol, Vol. 43, 6115 https://doi.org/10.1021/es901511h

4. Hester, S., Moore, T., Padgett, W.T., Murphy, L., Wood, C.E., Nesnow, S., 2012. The Hepatocarcinogenic conazoles: cyproconazole, epoxiconazole, and propiconazole induce a common set of toxicological and transcriptional responses. Toxicological Sciences, Vol. 127, pp. 54-65. https://doi.org/10.1093/toxsci/kfs086

5. Hrouzková, S., Matisová, E., 2012. Endocrine disrupting pesticides. Pesticide-Advances in Chemical and Botanical Pesticides, pp. 99-126.

6. Hvězdová, M., Kosubová, P., Košíková, M., Scherr, K. E., Šimek, Z., Brodský, L., Šudoma, M., Škulcová, L., Sáňka, M., Svobodová, M., Krkošková, L., Vašíčková, J., Neuwirthová, N., Bielská, L., Hofman, J. 2018. Currently and recently used pesticides in Central European arable soils. Science of the Total Environment, Vol. 613-614, pp. 361-370 http://www.sciencedirect.com/science/article/pii/S0048969717323926/

7. Köck-Schulmeyer, M., Ginebreda, A., Postigo, C., Garrido, T., Fraile, J., López de, A. M., Barceló, D. 2014. Four-year advanced monitoring program of polar pesticides in groundwater of Catalonia (NE-Spain). Science of The Total Environment, Vol. 470-471, pp. 1087-1098

8. LR Aplinkos Ministro İsakymas. Dèl cheminemis medžiagomis užterštų teritorijų tvarkymo aplinkos / apsaugos reikalavimu patvirtinimo. $2008 \mathrm{~m}$. balandžio $30 \mathrm{~d}$. Nr. D1-230 Vilnius [In Lithuanian]

9. McManus, S.-L., Coxon, C., Mellander, P.-E., Danaher, M., Richards, K.. Hydrogeological characteristics influencing the occurrence of pesticides and pesticide metabolites in groundwater across the Republic of Ireland. Science of The Total Environment, Vol. 601-602, Iss. 1, pp. 594-602. https://doi.org/10.1016/j.scitotenv.2017.05.082

10. Mikilevičius M. 2010. Pesticidu sandèliu poveikis geologinei aplinkai. „Geologijos akiračiai“ No. 3-4. [In Lithuania]

11. Mortl, M., Maloschik, E., Juracsek, J., Szekacs, A., 2010. Pesticide contamination in surface water and soil in Hungary. Proceedings of the 9th Alps-Adria Scientific Workshop, Špičák, Czech Republic, pp. 12-17 April 2010

12. Taurozaitė K. Buvusių pesticidų sandèlių teritorijų užterštumo pesticidų likučiais vertinimas. Available at https://epublications.vu.lt/object/elaba:2029732/ (Accessed 06/09/2017) [In Lithuanian]

13. UNEP, 2016. Stockholm Convention on Persistent Organic Pollutants Webpage With Actualized Lists of POPs. Available at http://chm.pops.int/TheConvention/ThePOPs/ListingofPOPs/ tabid/2509/Default.aspx United Nations Environmental Program.

14. Vonberg, D., Hofmann, D., Vanderborght, J., Lelickens, A., Koppchen, S., Putz, T., et al., 2014a. Atrazine soil core residue analysis from an agricultural field 21 years after its ban. Journal of Environmental Quality, Vol. 43, $1450-1459$. https://doi.org/10.2134/jeq2013.12.0497

15. Vonberg, D., Vanderborght, J., Cremer, N., Putz, T., Herbst, M., Vereecken, H., 2014b. 20 years of long-term atrazine monitoring in a shallow aquifer in western Germany. Water Research, Vol. 50, 294-306. https://doi.org/10.1016/j.watres.2013.10.032

16. Zhao Y.Y., Pei Y.S. 2012. Risk evaluation of groundwater pollution by pesticides in China: a short review. Procedia Environmental Sciences, Vol. 13 pp. 1739-1747.https://doi.org/10.1016/j.proenv.2012.01.167 